\title{
Contrast sensitivity after refractive lens exchange with a multifocal diffractive aspheric intraocular lens
}

\author{
Sensibilidad al contraste tras cirugía de cristalino transparente con lente intraocular multifocal \\ asférica difractiva
}

Teresa Ferrer-Blasco ${ }^{1}$, Santiago García-Lázaro ${ }^{1}$, César Albarrán-Diego ${ }^{1}$, Cari Pérez-Vives ${ }^{1}$, Robert Montés-Micó ${ }^{1}$

\begin{abstract}
Purpose: To evaluate distance and near contrast sensitivity (CS) under photopic and mesopic conditions before and after refractive lens exchange (RLE) and implantation of the aspheric AcrySof ${ }^{\circledR}$ ReSTOR $^{\circledR}(\mathrm{SN} 6 \mathrm{AD} 3$ model) intraocular lens $(\mathrm{IOL})$ Methods: Seventy-four eyes of 37 patients after RLE underwent bilateral implantation with the aspheric AcryS Of ReSTOR IOL. The patient sample was divided into myopic and hyperopic groups. Monocular uncorrected visual acuity at distance and near (UCVA and UCNVA, respectively) and monocular best corrected visual acuity at distance and near (BCVA and BCNVA, respectively) were measured before and 6 months postoperatively. Monocular CS function was measured at three different luminance levels $\left(85,5\right.$ and $\left.2.5 \mathrm{~cd} / \mathrm{m}^{2}\right)$ before and after RLE. Post-implantation results at 6 months were compared with those found before surgery.

Results: Our results revealed that patients in both groups obtained good UCVA and BCVA after RLE at distance and near vision in relation to pre-surgery values. No statistically significant differences were found between the values of CS pre and post-RLE at distance and near, at any lighting condition and spatial frequency ( $p>0.002$ ).

Conclusions: Refractive lens exchange with aspheric AcrySof ReSTOR IOL in myopic and hyperopic population provided good visual function and yield good
\end{abstract} distance and near CS under photopic and mesopic conditions.

Keywords: Lens implantation, intraocular; Lens cristalline/surgery; Myopia/surgery; Hyperopia/physiopathology; Phacoemulsification; Visual acuity

\section{RESUMEN}

Propósito: El propósito de este estudio fue evaluar la sensibilidad al contraste antes de la extracción de cristalino transparentey tras la implantación de la lente intraocular asférica AcrySof ${ }^{\circledR}$ ReSTOR ${ }^{\circledR}($ SNGAD3) bajo condiciones fotópicas y mesópicas.

Métodos: Seestudiaron 74 ojos de 37 pacientes tras ser sometidos a cirugía de cristalino transparente bilateral con la lente intraocular AcrySof RESTOR (SNGAD3 model). LOS pacientes fueron divididos en dos grupos: miopes e hipermétropes. A ambos grupos se les midió antes y a los 6 meses de la intervención quirúrgica la agudeza visual con la mejor corrección monocular en visión de lejos y de cerca, y la agudeza visual monocular no corregida para visión de lejos y de cerca. La función de sensibilidad al contraste fue medida a tres diferentes niveles de iluminación $\left(85,5\right.$ y $\left.2.5 \mathrm{~cd} / \mathrm{m}^{2}\right)$ antes y después de la cirugía. Los resultados post-quirúrgicos a 6 meses fueron comparados con los pre-quirúrgicos.

Resultados: Los pacientes de ambos grupos mostraron buenos niveles de agudeza visual no corregida y con la mejor corrección tras la implantación de la lente intraocular para visión de lejos y cerca en comparación a los valores pre-quirúrgicos. No se encontraron diferencias estadísticamente significativas entre los valores pre y postquirúrgicos de sensibilidad al contraste para cualquier distancia, frecuencia espacial o nivel de iluminación $(p>0,002)$.

Conclusiones: La cirugía de cristalino transparente con la lente intraocular asférica AcrySofReSTORen pacientes miopes ehipermétropes proporciona una buena función visual en visión de lejos y de cerca bajo condiciones fotópicas y mesópicas.

Descriptores: Implantación de lentes intraoculares; Cristalino/cirugía; Miopía/cirugía; Hiperopia/fisiopatología; Hiperopia/cirugía; Facoemulsificación; Agudeza visual

\section{INTRODUCTION}

Currently, refractive lens exchange (RLE) surgery in presbyopes patients with high myopia or hyperopia is focused not only on restoring visual acuity (VA) at distance and near but also on providing the best visual quality to patients. Bifocal refractive ${ }^{(1-3)}$, diffractive ${ }^{(4-7)}$, spherical hybrid $^{(8-11)}$ and aspheric hybrid ${ }^{(12-16)}$ IOLs generate two focal points along the optical axis to provide good monocular uncorrected distance and near visual acuity (UCVA and UNVA, respectively) as well as functional intermediate vision. The bifocal IOLs have also been implanted in RLE with good results at distance and near vision ${ }^{(17-25)}$. Recent studies with the hybrid spherical AcrySof ${ }^{\circledR} \operatorname{ReSTOR}^{\circledR} \mid \mathrm{OL}$ (AIcon Laboratories, Inc.) $)^{(19-21,24,25)}$ in RLE surgery report satisfactory visual results. These hybrids IOLs combine refractive and diffractive optics to reduce the disadvantages of conventional refractive and diffractive IOLs in terms of contrast sensitivity. (CS) (26)

Wavefront sensing technology recently has been applied in the design of news IOLs. The aspheric AcrySof ReSTOR (SN6AD3 model) was designed to produce negative spherical aberration (SA) to compensate the positive SA of the cornea ${ }^{(27)}$. This design aims to decrease unwanted visual phenomena associated with multifocal IOL performance and to increase the depth of focus, thereby improving image quality ${ }^{(12-16)}$.

The contrast sensitivity function (CSF) gives information on visual performance for a range of object scales. The key question to be answered is whether this visual performance given by CSF in patients implanted with aspheric IOLs in RLE treatment is better or worse than
Submitted for publication: August 27,2012

Accepted for publication: December 10, 2012

Study carried out at Optics Department, University of Valencia, Spain

Optics Department, University of Valencia, Spain.
Funding: This study was supported in part by Ministerio de Ciencia e Innovación Research Grant to Robert Montés-Micó (\#SAF2009-13342\#)

Disclosure of potential conflicts of interest: T.Ferrer-Blasco, None; S.García-Lázaro, None; C.Alabarrán-Diego, None; R.Montés-Micó, None.

Correspondence address: Santiago García-Lázaro PhD. Optics Department, Faculty of Physics. University of Valencia. C/ Dr. Moliner, 50. 46100. Burjassot (Valencia). SPAIN.

E-mail: santiago.garcia-lazaro@uv.es 
the natural lens. In addition, it could detect differences, in terms of visual performance, between myopic and hyperopic eyes.

The purpose of this study was to show the visual quality by the CSF of patients implanted with the aspheric AcrySof ReSTOR SN6AD3 $I O L$, as a function of the illumination level under distance and near conditions, in 74 healthy, non-cataractous eyes divided into two groups (myopic and hyperopic) before and after RLE.

\section{METHODS}

\section{StUdY DESIGN}

The present prospective study was carried out on 74 consecutive eyes of 37 patients bilaterally implanted with the aspheric AcrySof ReSTOR IOL. Inclusion criteria were age between 45 and 70 years and the motivation to no longer wear any form of spectacle or contact lens correction for distance and near. Exclusion criteria included $\geq 1$ Diopters (D) of corneal astigmatism, history of glaucoma or retinal detachment, corneal disease, previous corneal or intraocular surgery, abnormal iris, pupil deformation, macular degeneration or retinopathy, neuro-ophthalmic disease and history of prior ocular inflammation. The tenets of the Declaration of Helsinki were followed in this research. Informed consent was obtained from all patients after the nature and possible consequences of the study were explained. Approval from the Institutional Review Board was obtained.

Before the RLE procedure, patients underwent a complete ophthalmologic examination, including manifest and cycloplegic refraction, keratometry, slit-lamp biomicroscopy, Goldmann applanation tonometry, and binocular indirect ophthalmoscopy through dilated pupils. Axial length and anterior segment biometry were measured with the Zeiss Humphrey IOL Master biometer (Carl Zeiss Meditec, Inc., Dublin, CA). The SRK/T formula was used for the myopic patients (all myopic patients with axial length $>24 \mathrm{~mm}$ ). The Holladay II formula was used for IOL power calculation in hyperopic patients (all hyperopic patients with axial length $<24 \mathrm{~mm}$ ). The targeted refraction was emmetropia in all cases.

All surgeries in this study were performed by phacoemulsification with the Infiniti Vision System (Alcon, Fort Worth, TX) using topical anaesthesia and a clear corneal 2.2-3.2 mm incision. Phacoemulsification was followed by irrigation and aspiration of the cortex, and IOL implantation in the capsular bag. There were no complications in any of the cases.

\section{IOL SPECIFICATIONS}

The aspheric AcrySof ReSTOR SN6AD3 IOL uses apodization, diffraction, and refraction. The apodized diffractive region is within the central $3.6 \mathrm{~mm}$ optic zone of the IOL. This area comprises 12 concentric steps of gradually decreasing (1.3 to $0.2 \mathrm{~mm}$ ) height, creating multifocality from distance to near ( 2 foci). The refractive part of the optic surrounds the apodized diffractive region. This area directs light to a distant focal point for larger pupil diameters and is dedicated to vision at distance. The overall diameter of the $\mathrm{IOL}$ is $13.0 \mathrm{~mm}$ and the optic diameter, $6.0 \mathrm{~mm}$. The IOL power used in this study varied from +10.00 to $+30.00 \mathrm{D}$ and incorporated a $+4.00 \mathrm{D}$ near addition (add). The IOL has an aspheric profile to correct positive SA of the cornea. The IOL material includes a blue light-filtering chromophore. It has been shown that the use of a blue-light filter is advisable because it prevents ultraviolet light alterations to the retina without disturbing CS and chromatic vision ${ }^{(28,29)}$

\section{Visual PERFormance MEASURES}

Monocular uncorrected and best corrected visual acuity at distance and near (UCVA, UCNVA, BCVA and BCNVA, respectively) were measured before and after 6 months post-surgery. The measurements in distance vision were measured using 100\% contrast Early
Treatment Diabetic Retinopathy Study (ETDRS) charts (Optec 6500; Stereo Optical Co Inc, Chicago, III) under photopic conditions (85 candelas per square meter $\left[\mathrm{cd} / \mathrm{m}^{2}\right]$ ) at $4 \mathrm{~m}$. The measurements in near vision were measured using the Logarithmic Visual Acuity Chart 2000 New ETDRS (Precision Vision, LaSalle, III) at $40 \mathrm{~cm}$ under photopic conditions $\left(85 \mathrm{~cd} / \mathrm{m}^{2}\right)$. The safety index of the procedure (ratio mean BCVA postoperative/mean BCVA preoperative) and the efficacy index (mean UCVA postoperative/mean BCVA preoperative) were calculated at 6 month after surgery.

Monocular photopic and mesopic CS was measured with best distance correction using the Stereo Optical Functional Acuity Contrast Test (FACT Stereo Optical, Chicago, IL) in both groups before and 6 months after implantation. Absolute values of log10 CS were obtained for each combination of patient, spatial frequency, and luminance; means and standard deviations were calculated. The levels of chart luminance were 85,5 and $2.5 \mathrm{~cd} / \mathrm{m}^{2}$, the first being photopic (i.e. the luminance recommended in the manufacturer's guidelines) and the others mesopic: room illumination was at similar levels. CS was measured first at the photopic level and then at the mesopic level. Patients were given 5 minutes to adapt to each level before testing. Pupil diameters were measured in each eye using a Colvard pupillometer (OASIS Medical Inc, Glendora, CA) under photopic and mesopic illumination conditions.

\section{Data analysis}

All examinations were performed preoperatively and 6 months after IOL implantation by one clinician who was unaware of the objective of the study. Normality was checked by the Shapiro-Wilk test. Correlation analysis was performed to assess the differences between pre- and post-surgery outcomes at far and near and correlations in the CS measured at the 3 lighting conditions. Bonferroni correction was applied for multiple tests of correlation for the 5 frequencies $(P<0.01 / 5)$. A probability less than $0.2 \%(P<0.002)$ was considered statistically significant.

\section{RESULTS}

Seventy-four eyes of 37 patients had RLE with ReSTOR SN6AD3 IOL. Eyes were divided into two groups, myopic ( $n=18,11$ female, 7 male) and hyperopic ( $n=19,10$ female, 9 male). Patients' demographics are shown in table 1 . There was no statistically significant differences in age or pupil diameter under mesopic conditions between-groups $(p>0.01)$. However, there were significant differences for pupil diameter under photopic conditions $(p<0.01)$. After surgery and IOL implantation, the pupils of all patients were round, without iris trauma, and showed good responsiveness to light. All eyes were available for examination at 6 months.

At 6 months after IOL implantation, the residual mean spherical equivalent (SE) refractive error was $-0.12 \pm 0.40 \mathrm{D}$ and $-0.04 \pm 0.46$ in myopic and hyperopic groups respectively. After surgery, none of the eyes required a secondary intervention. No potentially sight threatening complications such as persistent corneal edema, pupillary block, retinal detachment or endophthalmitis were observed during the postoperative period. In addition, no eye was in the need of Nd:YAG capsulotomy up to the postoperative last visit.

Table 2 shows the VA values before and after the IOL implantation for distance and near. In myopic group the safety index (ratio mean BCVA postoperative/mean BCVA preoperative) was 1.05 and 1.22 in distance and near vision respectively. The efficacy index (mean UCVA postoperative/mean BCVA preoperative) was 0.85 and 1.14 in distance and near vision respectively. In hyperopic group the safety index was 1.02 and 1.14 in distance and near vision respectively. The efficacy index was 0.85 and 1.13 in distance and near vision respectively.

The mean values of log10CS before and after RLE with the aspheric AcrySof ReSTOR IOL implantation are plotted as a series of CSFs in figure 1 for the myopic group and in figure 2 for the hyperopic group. 
Left column shows distance CSFs at the 3 luminance levels $(85,5$ and $2.5 \mathrm{~cd} / \mathrm{m}^{2}$ ) and right column shows the results of the measurements at near conditions. For comparison, mean measurements for myopic eyes implanted with spherical AcrySof ReSTOR SA60D3 IOL found by Blaylock et al. ${ }^{(21)}$ are included in figure 1. Similarly, mean measurements for hyperopic eyes implanted with the same IOL found by Ferrer-Blasco et al. ${ }^{(22)}$ are included in figure 2. To explore the statistical significance of differences between pre- and post-RLE groups, $t$-tests were performed on the comparable data of the two groups (absolute log10CS values) at each spatial frequency and illumination level. The results showed no statistically significant differences between the values pre- and post-RLE at any distance, lighting condition and spatial frequency $(P>0.002)$.

Table 1. Demographic characteristics of participants

\begin{tabular}{|c|c|c|}
\hline & $\begin{array}{l}\text { Myopic } \\
\text { group }\end{array}$ & $\begin{array}{c}\text { Hyperopic } \\
\text { group }\end{array}$ \\
\hline Number of eyes & 36 & 38 \\
\hline Age (years) & $49.63 \pm 4.15$ & $51.29 \pm 5.33$ \\
\hline Range of age (years) & $46-57$ & $47-60$ \\
\hline Gender (Male/Female) & $7 / 11$ & $9 / 10$ \\
\hline IOL power (D) & $12.66 \pm 2.06$ & $26.12 \pm 1.55^{*}$ \\
\hline Range IOL power (D) & $10-15.5$ & $24-30$ \\
\hline Axial length (mm) & $25.61 \pm 0.78$ & $21.88 \pm 0.62^{*}$ \\
\hline Range axial length (mm) & $23.67-27.45$ & $20.16-23.31$ \\
\hline Preoperative sphere (D) & $-6.55 \pm 1.99$ & $4.76 \pm 1.42^{*}$ \\
\hline Range preoperative sphere (D) & $4.25-11$ & $3-7$ \\
\hline Preoperative cylinder (D) & $0.48 \pm 0.31$ & $0.33 \pm 0.35$ \\
\hline Range preoperative cylinder (D) & $0-1.00$ & $0-0.75$ \\
\hline \multicolumn{3}{|l|}{ Preoperative keratometry (K) } \\
\hline $\mathrm{K} 1$ (D) & $44.46 \pm 1.21$ & $42.98 \pm 1.41^{*}$ \\
\hline K2 (D) & $44.71 \pm 1.23$ & $43.63 \pm 1.51$ \\
\hline Range preoperative keratometry $(\mathrm{K})$ & $42-46$ & $40.5-47$ \\
\hline \multicolumn{3}{|c|}{ Postoperative mean pupil diameter (mm) } \\
\hline $85 \mathrm{~cd} / \mathrm{m}^{2}$ & $4.39 \pm 0.78$ & $3.48 \pm 0.81^{*}$ \\
\hline $5 \mathrm{~cd} / \mathrm{m}^{2}$ & $5.77 \pm 0.59$ & $5.02 \pm 0.57$ \\
\hline $2.5 \mathrm{~cd} / \mathrm{m}^{2}$ & $6.06 \pm 0.52$ & $5.86 \pm 0.57$ \\
\hline
\end{tabular}

$\mathrm{IOL}=$ intraocular lens; $\mathrm{D}=$ dioptres; means \pm standard deviation.

${ }^{*}=$ means statistically significant differences between both systems.

\section{DISCUSSION}

The removal of the crystalline lens and replacement with a pseudophakic lens for the purposes of reducing or eliminating refractive errors has been labelled with many titles, including clear lensectomy, clear lens phacoemulsification, clear lens replacement, clear lens exchange, presbyopic lens exchange, and RLE. Several studies evaluating the clinical, functional, and quality-of-life outcomes after implantation of the multifocal spherical IOLs $s^{(17-22,24,25)}$ show that these lenses improves high level of distance vision with additional benefit of increased range of near vision without additional correction in non-cataractous eyes. Blaylock et al.(21) and Ferrer-Blasco et al.(22) evaluated the CS under photopic and mesopic conditions before and after implantation of the spherical AcrySof ReSTOR IOL. These authors found postoperatively a reduction in mesopic CS in relation to photopic CS but with a performance comparable to the CS preoperative. This study is the first one assessing CS after RLE and implantation of a multifocal IOL with an aspheric design.

Our results revealed that aspheric AcrySof ReSTOR IOL provided good and comparable safety and efficacy indexes in both groups. Our values agree with those found previously in 112 patients after RLE with bilateral spherical AcrySof ReSTOR IOL ${ }^{(19)}$. There was no statistically significant difference between pre and postoperative BCVA in hyperopic group ( $p>0.01$ ), however we found statistically significant difference in the myopic group ( $p<0.01$; see table 2 ). Magnification and minimization of the retinal image in myopic and hyperopic patients, respectively, may play a significant role in this difference.

If we focus now on CS we must first point out that the light distribution between distance and near foci depends on pupil diameter and varies from approximately $40 \%$ to $90 \%$ of the light to the distance focus for this $1 \mathrm{OL}^{(26)}$. Pupil diameter postoperative in myopic group under photopic conditions was $4.39 \pm 0.78 \mathrm{~mm}$, so the percentage of light for the distance/near focus was about 80/20. In the mesopic conditions pupil diameter was $5.77 \pm 0.59 \mathrm{~mm}$, and $6.06 \pm 0.52 \mathrm{~mm}$ for $2.5 \mathrm{~cd} / \mathrm{mm}^{2}$, about $90 / 10$ of the light goes to distance/near focus. In hyperopic group the pupil diameter measured postoperative was $3.48 \pm 0.81 \mathrm{~mm}$ and $5.02 \pm 0.57 \mathrm{~mm}$ in photopic and mesopic conditions respectively, so the percentage of the light for the distance/ near focus was about 70/30 and 85/15.

Analysing the results for distance, under photopic conditions, performance was very similar in both groups when compare the results of CSFs before and after surgery. There is some loss in photopic retinal image contrast with the aspheric AcrySof ReSTOR IOL although this difference was not significant ( $p>0.002$ ). Due to diffractive nature of the IOL, for small pupils a maximum of $40 \%$ of the total light passing through the pupil contributes to either the distance or near image, and the remainder of the light decreases retinal image contrast ${ }^{(26)}$. The light energy focused on the distance focus was about $80 \%$ and $70 \%$ in myopic and hyperopic groups respectively

Table 2. Monocular visual acuity results for distance and near vision. Mean and standard deviation logMAR (logarithm of the minimum angle of resolution) values before and after 6 months post-AcrySof ReSTOR SN6AD3IOL implantation

\begin{tabular}{|c|c|c|c|c|c|c|}
\hline & \multicolumn{3}{|c|}{ Myopic group } & \multicolumn{3}{|c|}{ Hyperopic group } \\
\hline & Before & After & p-value & Before & After & p-value \\
\hline \multicolumn{7}{|c|}{ Distance (4 m) } \\
\hline UCVA & $0.90 \pm 0.10$ & $0.08 \pm 0.15$ & $<0.001$ & $0.86 \pm 0.12$ & $0.11 \pm 0.14$ & $<0.001$ \\
\hline BCVA & $0.03 \pm 0.05$ & $0.01 \pm 0.02$ & $<0.01$ & $0.05 \pm 0.12$ & $0.04 \pm 0.10$ & 0.30 \\
\hline \multicolumn{7}{|c|}{ Near $(40 \mathrm{~cm})$} \\
\hline UCNVA & $0.42 \pm 0.11$ & $0.03 \pm 0.05$ & $<0.001$ & $0.91 \pm 0.08$ & $0.05 \pm 0.08$ & $<0.001$ \\
\hline BCNVA & $0.10 \pm 0.01$ & $0.01 \pm 0.02$ & $<0.01$ & $0.10 \pm 0.01$ & $0.04 \pm 0.06$ & $<0.01$ \\
\hline
\end{tabular}

UCVA= uncorrected logMAR distance visual acuity, BCVA= best distance-corrected logMAR visual acuity, UCNVA= uncorrected near logMAR visual acuity, BCNVA= best distance-corrected near logMAR visual acuity. 
MYOPIC
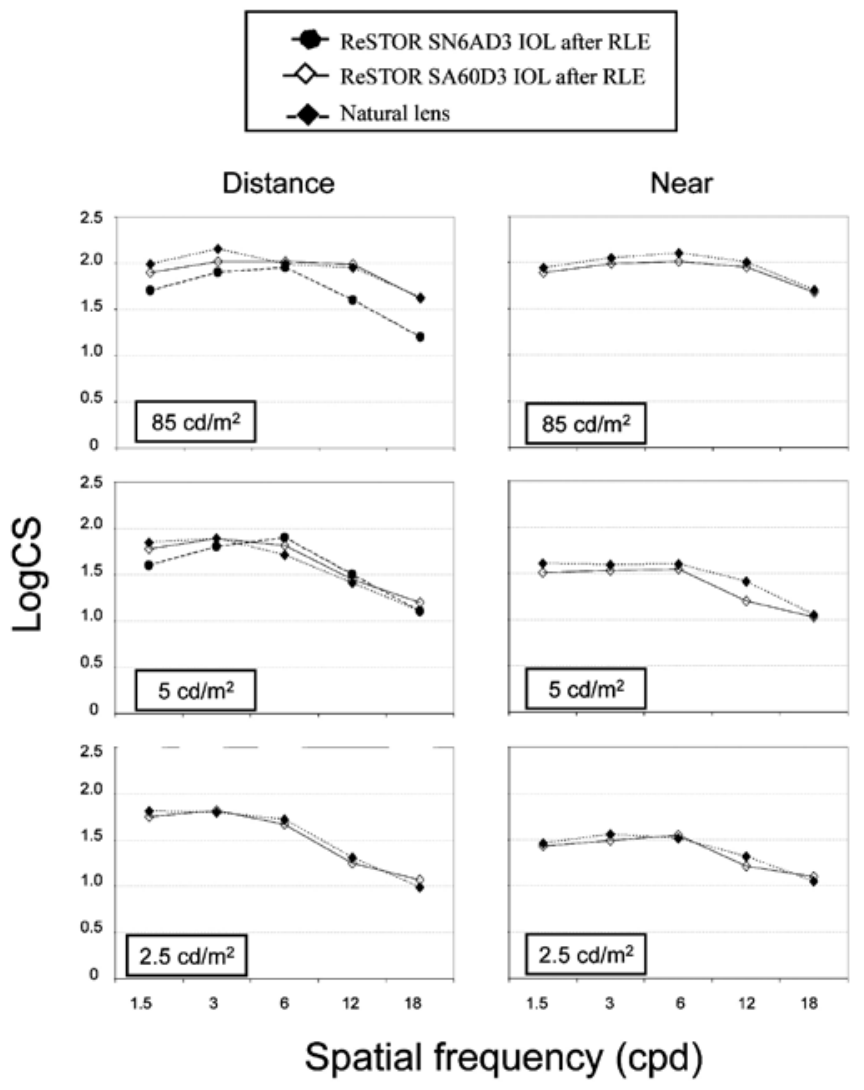

$\mathrm{CS}=$ contrast sensitivity; $\mathrm{cpd}=$ cycles per degree.

Figure 1. Contrast sensitivity functions before (natural lens) and after refractive lens exchange with the aspheric AcrySof ReSTOR implantation in myopic group as a function of the distance and FACT chart luminance $\left(85,5\right.$ and $\left.2.5 \mathrm{~cd} / \mathrm{m}^{2}\right)$. For comparison, results for spherical AcrySof ReSTOR IOL from Blaylock et al. ${ }^{(21)}$ are included.

and these values are enough to achieve a CS comparable with the natural lens, both with appropriate distance correction. Comparing between groups, at high spatial frequencies, CSF showed lower values in myopic than hyperopic patients under photopic conditions, although these differences were not statistically significant. A recent study with another diffractive IOL design has shown that a $65 \%$ of light energy for the distance focus is also acceptable for achieving good photopic distance $\mathrm{CS}^{(12)}$.

Under low lighting conditions, there is a little reduction in CSF results obtained with multifocal IOLs compared with the results with the natural lens at $5 \mathrm{~cd} / \mathrm{m}^{2}$ and $2.5 \mathrm{~cd} / \mathrm{m}^{2}$, particularly at higher spatial frequencies in both groups. This trend agrees with classic data for the effect of luminance level on $\mathrm{CS}^{(30)}$. At these mesopic levels, pupil diameters are substantially larger, and it seems reasonable to attribute the observed reduction in mesopic CS at higher spatial frequencies to the additional blur introduced by the larger diameter, out-of-focus zones of the multifocal IOL.

At near, the photopic and mesopic CSFs were similar pre- and post-RLE in both groups. These results agree with those found previously by Ferrer-Blasco et al.(22). In comparison with distance vision the reduction of CS under dim conditions correlated with the reduction of light energy concentrated at the near focus. In photopic the percentage of the light for the distance focus were between $80 \%$ and $70 \%$ but, in mesopic conditions, the percentage of the light contributes to near image is less than $30-20 \%$. These percentages leading to noticeably worse the results of CS at near. Increasing pupil
HYPEROPIC

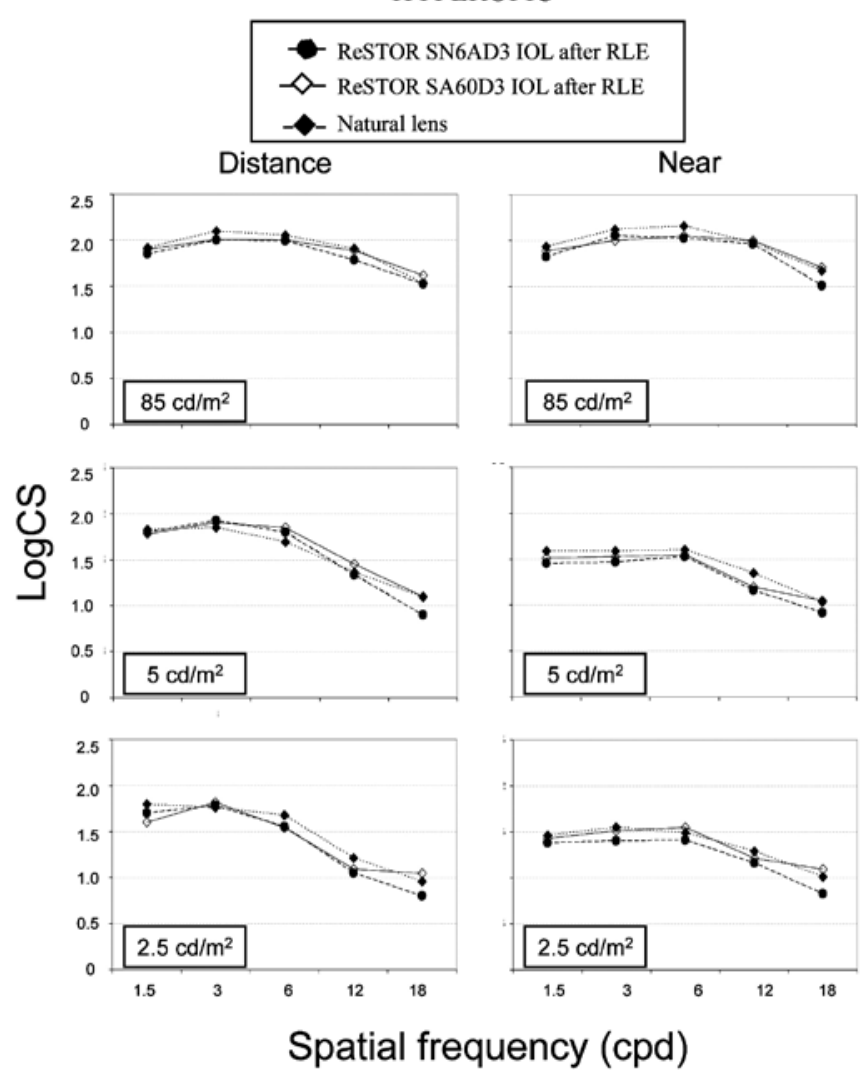

$\mathrm{CS}=$ contrast sensitivity; $\mathrm{cpd}=$ cycles per degree.

Figure 2. Contrast sensitivity functions before (natural lens) and after refractive lens exchange with the aspheric AcrySof ReSTOR implantation in hyperopic group as a function of the distance and FACT chart luminance $\left(85,5\right.$ and $\left.2.5 \mathrm{~cd} / \mathrm{m}^{2}\right)$. For comparison, results for spherical AcrySof ReSTOR IOL from Ferrer-Blasco et al. ${ }^{(22)}$ are included.

diameter implies that more light is distributed for the distance foci and then better CS is expected for distance CSFs compared to near CSF at mesopic levels. These differences are slightly minimized due to the myosis during the accommodative process. One should consider that the loss in retinal image contrast has little effect on acuity as measured with high-contrast letters, since contrast can be reduced to quite low levels before acuity is affected ${ }^{(30)}$.

For comparison in myopic group we included in figure 1 the mean values obtained for the spherical AcrySof ReSTOR as found by Blaylock et at. ${ }^{(21)}$ in 19 myopic patients (mean preoperative SE -3.89 $\pm 2.14 \mathrm{D}$ ). We should point out that these CS results were measured at 50 foot-candles in photopic level and 3 foot-candles in mesopic level with the SIFIMAV Vision Tester (Designs For Vision; Sydney, Australia). Caution should be exercised when comparing results, among different studies. The differences in conditions and measure systems between studies may play a role in the differences found but is obvious that the results of spherical AcrySof ReSTOR return to be lower.

In hyperopic group we had included in figure 2 the results obtained by Ferrer-Blasco et al. ${ }^{(22)}$ in 50 hyperopic patients (mean preoperative SE $2.18 \pm 1.17$ ) at the same conditions and with the same test in patients implanted with the spherical AcrySof ReSTOR. At higher spatial frequencies, the CS results of the spherical AcrySof ReSTOR IOL were lower compared with CS results of the aspheric IOL and natural lens. Differences between both IOLs become more evident when lighting conditions are reduced and pupil diameter is increased. This is an expected result considering the reduction of ocular SA for large 


\section{$\diamond$ Myopic group}

Hyperopic group
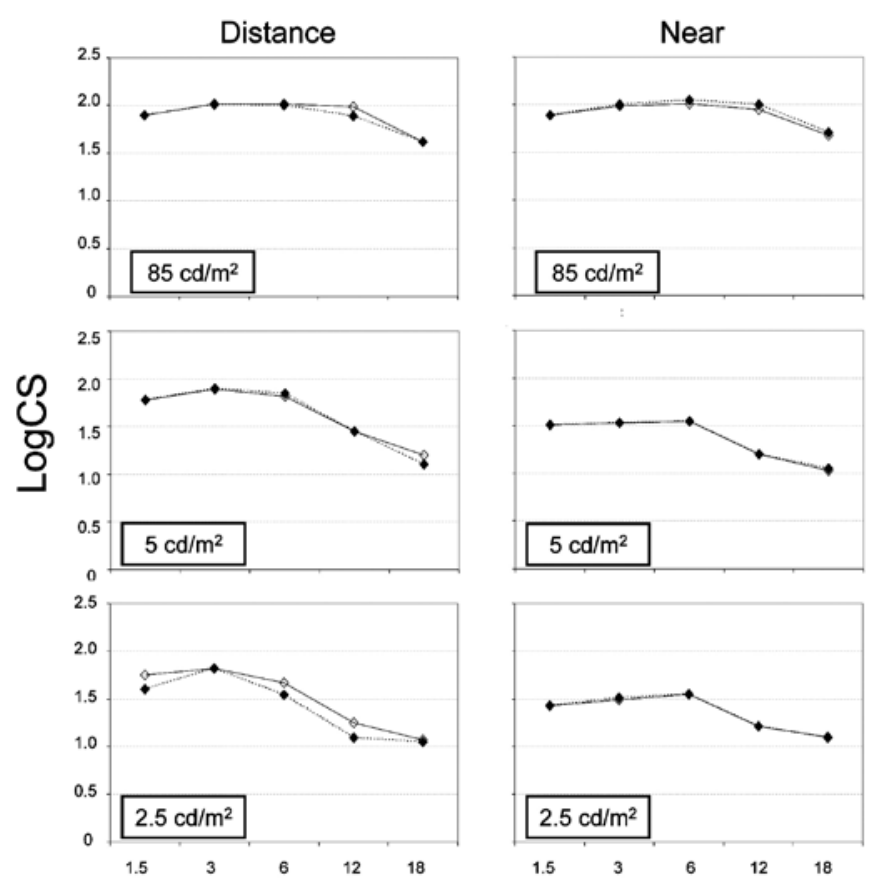

\section{Spatial frequency $(\mathrm{cpd})$}

$\mathrm{CS}=$ contrast sensitivity; $\mathrm{cpd}=$ cycles per degree.

Figure 3. Contrast sensitivity functions after refractive lens exchange with the aspheric AcrySof ReSTOR implantation in myopic and hyperopic group as a function of the distance and FACT chart luminance $\left(85,5\right.$ and $\left.2.5 \mathrm{~cd} / \mathrm{m}^{2}\right)$.

pupil diameters when an aspheric IOL is implanted, compared with that found in eyes with a spherical $I O L^{(27)}$. Maxwell et al. ${ }^{(23)}$ compared the optical performance in RLE with 6 presbyopia-correcting IOLs of different designs (3 spherical models: Crystalens AT-50SE, AcrySof ReSTOR SA60D3 and ReZoom NXG1; 3 aspheric models: AcrySof ReSTOR SN6AD3, Acri.Lisa 366D, and Tecnis ZM900). They found that the aspheric AcrySof ReSTOR SN6AD3 IOL showed superior optical properties when the modulation transfer function and the United States Air Force 1951 Resolution Target in optical bench testing were analyzed.

If we now compare the post-surgery CSF results found in both groups, similar outcomes were reported (see figure 3). Statistically significant differences were found related to pupil size between both groups $(p<0.01)$, the pupil size in myopic group was slightly higher compared to that found in the hyperopic group (see table 1). According to the light distribution between distance and near foci, in this group a higher percentage of the light contributes to distance image but we need also to consider that there is an increasing effect of higher order optical aberrations especially in hybrid IOLs when the pupil increases. The balance between the advantage and disadvantage of the large pupils (light distribution versus optical aberrations) could be the reason of finding similar results in both groups.

In general, the results found in both groups were similar in distance and near vision at the different lighting conditions (Figure 3) and pre and post-surgery (Figure 1 and 2) without statistically significant differences ( $p>0.002)$. Previous literature about CS with a multifocal
IOL found a reduction compared to that obtained with a monofocal $1 \mathrm{LL}^{(2)}$. Our results were similar possibly because in these patients there was already a high degree of contrast-reducing scatter previous surgery (natural eye), giving a reduced CSF as compared with normal young eyes. Replacing the scattering crystalline with an IOL would remove this scatter, even if the diffractive $\mathrm{IOL}$ itself reduced the retinal image contrast by its simultaneous bifocal properties.

In conclusion RLE with aspheric AcrySof ReSTOR in presbyopic population provided good visual function and yield good distance and near CS under photopic and mesopic conditions in myopic and hyperopic patients. Although mesopic CS is reduced at distance and near in relation to that found under photopic conditions, the performance is comparable to that obtained prior to surgery with the natural lens and better than the results obtained in patients implanted with spherical AcrySof ReSTOR. Further studies are needed to assess the stability, photic phenomena, such as starbursts and halos, patient satisfaction, the role of pupil size after this multifocal IOL implantation and intermediate visual acuity for comparison with others IOLs profiles.

\section{REFERENCES}

1. Leyland M, Pringle E. Multifocal versus monofocal intraocular lenses after cataract extraction. Cochrane Database Syst Rev. 2006;(4):CD003169. Update of Cochrane Database Syst Rev. 2003;(3):CD003169. Update in Cochrane Database Syst Rev. 2012; 9:CD003169.

2. Montés-Micó R, Alió JL. Distance and near contrast sensitivity function after multifocal intraocular lens implantation. J Cataract Refract Surg. 2003;29(4):703-11.

3. Montés-Micó R, España E, Bueno I, Charman WN, Menezo JL. Visual performance with multifocal intraocular lenses: mesopic contrast sensitivity under distance and near conditions. Ophthalmology. 2004;111(1):85-96.

4. Lindstrom RL. Food and Drug Administration study update. One year results from 671 patients with the 3M multifocal intraocular lens. Ophthalmology. 1993;100(1):91-7.

5. Walkow T, Liekfeld A, Anders N, Pham DT, Hartmann C, Wollensak J. A prospective evaluation of a diffractive versus a refractive designed multifocal intraocular lens. Ophthalmology. 1997;104(9):1380-6.

6. Schmidinger G, Simader C, Dejaco-Ruhswurm I, Skorpik C, Pieh S. Contrast sensitivity function in eyes with diffractive bifocal intraocular lenses. J Cataract Refract Surg. 2005;31(11):2076-83.

7. Alfonso JF, Fernández-Vega L, Señaris A, Montés-Micó R. Quality of vision with the Acri. Twin asymmetric diffractive bifocal intraocular lens system. J Cataract Refract Surg. 2007:33(2):197-202. Comment in J Cataract Refract Surg. 2007;33(2):173-4.

8. Kohnen T, Allen D, Boureau C, Dublineau P, Hartmann C, Mehdorn E, et al. European multicenter study of the AcrySof ReSTOR apodized diffractive intraocular lens. Ophthalmology. 2006;113(4):584.e1.

9. Alfonso JF, Fernández-Vega L, Baamonde MB, Montés-Micó R. Prospective visual evaluation of apodized diffractive intraocular lenses. J Cataract Refract Surg. 2007; 33(7):1235-43

10. Fernández-Vega L, Alfonso JF, Montés-Micó R, Amhaz H. Visual acuity tolerance to residual refractive errors in patients with an apodized diffractive intraocular lens. J Cataract Refract Surg. 2008;34(2):199-204.

11. de Vries NE, Webers CA, Montés-Micó R, Tahzib NG, Cheng YY, de Brabander J, et al. Long-term follow-up of a multifocal apodized diffractive intraocular lens after cataract surgery. J Cataract Refract Surg. 2008;34(9):1476-82.

12. Alfonso JF, Fernández-Vega L, Señaris A, Montés-Micó R. Prospective study of the Acri. LISA bifocal intraocular lens. J Cataract Refract Surg. 2007;33(11):1930-5.

13. Alfonso JF, Fernández-Vega L, Valcárcel B, Montés-Micó R. Visual performance after AcrySof ReSTOR aspheric intraocular lens implantation. J Optom. 2008;1:30-5.

14. Alió JL, Elkady B, Ortiz D, Bernabeu G. Clinical outcomes and intraocular optical quality of a diffractive multifocal intraocular lens with asymmetrical light distribution. J Cataract Refract Surg. 2008;34(6):942-8.

15. Alfonso JF, Puchades C, Fernández-Vega L, Montés-Micó R, Valcárcel B, Ferrer-Blasco T. Visual acuity comparison of 2 models of bifocal aspheric intraocular lenses. J Cataract Refract Surg. 2009;35(4):672-6.

16. Alfonso JF, Fernández-Vega L, Amhaz H, Montés-Micó R, Valcárcel B, Ferrer-Blasco T. Visual function after implantation of an aspheric bifocal intraocular lens. J Cataract Refract Surg. 2009;35(5):885-92.

17. Packer M, Fine $I H$, Hoffman RS. Refractive lens exchange with the array multifocal intraocular lens. J Cataract Refract Surg. 2002;28(3):421-4

18. Dick HB, Gross S, Tehrani M, Eisenmann D, Pfeiffer N. Refractive lens exchange with an array multifocal intraocular lens. J Refract Surg. 2002;18(5):509-18.

19. Fernández-Vega L, Alfonso JF, Rodríguez PP, Montés-Micó R. Clear lens extraction with multifocal apodized diffractive intraocular lens implantation. Ophthalmology. 2007;114(8):1491-8 
20. Goes FJ. Refractive lens exchange with the diffractive multifocal Tecnis ZM900 intraocular lens. J Refract Surg. 2008;24(3):243-50.

21. Blaylock JF, Si Z, Aitchison S, Prescott C. Visual function and change in quality of life after bilateral refractive lens exchange with the ReSTOR multifocal intraocular lens. J Refract Surg. 2008;24(3):265-73.

22. Ferrer-Blasco T, Montés-Micó R, Cerviño A, Alfonso JF, Fernández-Vega L. Contrast sensitivity after refractive lens exchange with diffractive multifocal intraocular lens implantation in hyperopic eyes. J Cataract Refract Surg. 2008;34(12):2043-8. Comment in J Cataract Refract Surg. 2008;34(12):2005.

23. Maxwell WA, Lane SS, MD, Zhou F. Performance of presbyopia-correcting intraocular lenses in distance optical bench tests. J Cataract Refract Surg. 2009;35(1):166-71. Comment in J Cataract Refract Surg. 2010;36(6):1060-2; author reply 1062-3.

24. Leysen I, Bartholomeeusen E, Coeckelbergh T, Tassignon MJ. Surgical outcomes of intraocular lens exchange: five-year study. J Cataract Refract Surg. 2009;35(6):1013-8. 25. Alfonso JF, Fernández-Vega L, Valcárcel B, Ferrer-Blasco T, Montés-Micó R. Outcomes and patient satisfaction after presbyopic bilateral lens exchange with the ResTOR IOL in emmetropic patients. J Refract Surg. 2010:26(12):927-33.

26. Davison JA, Simpson MJ. History and development of the apodized diffractive intraocular lens. J Cataract Refract Surg. 2006;32(5):849-58.

27. Montés-Micó R, Ferrer-Blasco T, Cerviño A. Analysis of the possible benefits of aspheric intraocular lenses: review of the literature. J Cataract Refract Surg. 2009;35(1):172-81 Comment in J Cataract Refract Surg. 2009;35(6):962-3; author reply 963-4.

28. Rodríguez-Galietero A, Montés-Micó R, Muñoz G, Albarrán-Diego C. Comparison of contrast sensitivity and color discrimination after clear and yellow intraocular lenses implantation J Cataract Refract Surg. 2005:31(9):1736-40.

29. Rodríguez-Galietero A, Montés-Micó R, Muñoz G, Albarrán-Diego C. Blue-light filtering intraocular lens in patients with diabetes: contrast sensitivity and chromatic discrimination. J Catarac Refract Surg. 2005:31(11):2088-92.

30. Regan D, Neima D. Low-contrast letter charts as a test of visual function. Ophthalmology. 1983;90(10):1192-200.

\section{Simpósio Internacional de Córnea do Hospital de Olhos de Sorocaba}

\section{4 a 26 de outubro de 2013}

Sorocaba (SP)

\section{Organização:}

Hospital de Olhos de Sorocaba

\section{Informações:}

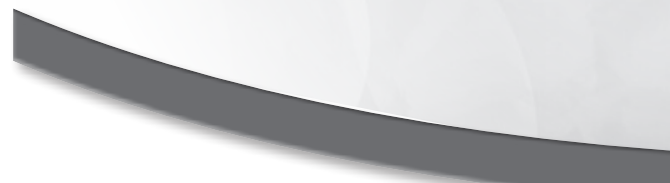

Tel.: (15) 3212-7077

E-mail: sinbos@bos.org.br 